\title{
Caloric restriction increases ratio of estrogen to androgen receptors expression in murine ovaries - potential therapeutic implications
}

\author{
Sylwia Słuczanowska-Głąbowska1*, Maria Laszczyńska², Katarzyna Piotrowska', Marta Grabowska², \\ Katarzyna Grymuła ${ }^{1}$ and Mariusz Z. Ratajczak ${ }^{1,3}$
}

\begin{abstract}
Both estrogens and androgens are involved in the development and normal functioning of the ovaries. It is also known that ovarian function is regulated by diet. The goal of this study was to estimate the expression of sex hormone receptors in ovaries of mice that were on a 9-month caloric restriction (alternate-day feeding) as compared to normal control animals fed ad libitum. We found that prolonged caloric restriction in mouse ovaries led to increased expression of estrogen receptors (ERs) but did not affect expression of the androgen receptor (AR). This increase in ER:AR ration as result of caloric restriction may lead to higher sensitivity to estrogens and upon return to normal diet may increase ovulation. Thus our observation shed more light on a role of beneficial effect of calorie restriction on female reproduction.
\end{abstract}

Keywords: Ovary, Mice, Androgen receptor, Estrogen receptors, Caloric restriction

\section{Introduction}

Estrogens and androgens are involved in the development and normal functioning of the ovaries. Estrogen, which is mainly synthesized in the ovary, is also involved in the development and functioning of other components of the female reproductive system. It is primarily expressed by preovulatory follicles under the influence of FSH [1]. In healthy premenopausal women, the main estrogen, $17 \beta$-estradiol, is produced in the ovaries. In postmenopausal women and in men, $17 \beta$-estradiol is produced in extra gonadal sites, mainly by aromatization of circulating testosterone in adipose tissue $[2,3]$. The main function of estrogen in females is to control the estrous cycle and regulate development and maturation of the reproductive tract. Ovarian-produced estrogens are essential for cell proliferation, follicular development, and growth as well as follicular atresia. Estrogens also augment the action of follicle-stimulating hormone (FSH), increase responsiveness of ovaries to gonadotropins, increase aromatase activity, and estrogen synthesis [1-5].

\footnotetext{
* Correspondence: sylwia@pum.edu.pl

'Department of Physiology Pomeranian Medical University, Powstańców Wielkopolskich 72, 70-111 Szczecin, Poland

Full list of author information is available at the end of the article
}

The biological effects of estrogen are mediated by two nuclear estrogen receptors (ERs): ER $\alpha$ and ER $\beta$. In the ovary, ER $\beta$ expression is predominant. In immature and adult animals, ER $\beta$ is found in the nuclei of granulosa cells of primary, secondary, and mature follicles, and a weak immunoreactive response is also detected in atretic follicle granulosa cells. Immunoreactivity for ER $\beta$ was also found in theca cells, luteal cells, interstitial cells, ovarian surface epithelium, and oocytes. By contrast, $E R \alpha$ is present in theca cells, interstitial cells, and in ovarian surface epithelium; low expression is noted in granulosa cells $[1,4,6,7]$. It is interesting that the number of ER $\alpha$ receptors is significantly reduced in animals in the nonbreeding season [1]. It has also been observed that, while ER $\alpha$ knockout female mice are infertile and do not ovulate, ER $\beta$ knockout female mice display impaired fertility, with reduced litter numbers and smaller litter size compared with wild type mice [5].

The androgens play an important regulatory role in the ovaries during follicular development and are responsible for follicle initiation and early growth $[1,8]$. The main androgen, androstendione, is synthesized from progestagens in theca cells under the influence of luteinizing hormone (LH) [9-11]. The androgens appear 
to be capable of improving the early stages of folliculogenesis in ovaries. In mammals, including in human, androgens are converted into estrogen, which regulates follicular development via binding to ERs during the reproductive life span. In aged mammals, only a small portion of androgens is converted into estrogens, and the androgens predominantly bind to the androgen receptor (AR) and may affect follicular development [8-13].

The ovarian AR is localized mainly in granulosa cells but is also found in oocytes, theca, and interstitial cells $[7,14-16]$. The follicles in the early stages of development express a larger number of AR proteins than those in more advanced stages. It is significant that expression of AR mRNA increases as the follicles make the transition from primordial to preantral follicles, and the expression of AR is highest in preantral follicles, gradually decreasing as the follicles mature. The $A R$ and its mRNA are developmentally regulated and are downregulated during FSH-stimulated preovulatory follicular development [7, 8, 14-17]. Granulosa cells in preantral and antral follicles constitute a crucial site for ARmediated action involved in maintaining follicle and embryo survival and optimal female fertility. The expression of the AR is higher in the ovaries of old female animals and postmenopousal women than in reproductive age women and animals in nonbreeding season $[1,7,8,12-19]$. In seasonally breeding animals, androgens play a crucial role in the transition from the breeding to the nonbreeding season and regulate follicular atresia. Animals in the breeding season exhibit all stages of follicular development, but in the nonbreeding season only preantral follicles are present [1].

It is well known that nutrition and energy metabolism influence reproductive function [20]. In human and other mammals, malnutrition delays the onset of puberty and leads to ovulation problems and embryonic mortality. Nutrients and metabolic hormones, including insulin and insulin-like growth factor 1 (IGF-1), are needed to maintain normal function of the hypothalmus-pituitary axis and also to maintain the reproductive cells in the gonads [20-23].

Caloric restriction (CR) is one of the factors that extends life span, and it minimizes the age-related dysfunction of many organs, including those of the reproductive system [24, 25]. It is known that decreased food intake leads to slower growth but also increased longevity $[21,24,26]$. Selesniemi et al. [22] showed that CR delays sexual maturation, extends female fertile lifespan, and leads to maintenance of the ovarian follicle reserve. Gutierrez et al. [27] showed that an increase in dietary intake leads to increased recruitment of small follicles during the first follicular wave of the estrous cycle but not to follicle selection and dominance. Armstrong et al. [28] observed a dietary-induced increase in aromatase activity in small follicles. Nelson et al. [29] reported that
CR delays the age-related loss of cycling capacity, the age-related increase in cycle length, and the age-related loss of primordial follicles [29].

Our recent morphological study [30] showed that the ovaries of 2.5-year-old wild type (WT) mice on CR appeared to be younger than 2.5-year-old wild type mice fed ad libitum. While ovaries of WT mice on CR still contained some follicles at different stages of development, ovaries in 2.5-year-old WT mice fed ad libitum were depleted of follicles. Similarly, we observed that the ovaries of 10-month-old female mice on CR had higher numbers of primordial, primary, and preantral follicles than the ovaries of mice fed ad libitum [25]. We also examined male mice on CR and we observed a $\sim 25 \%$ reduction in body weight in male mice on CR [25].

To better explain these observations, we examined the expression of ER and AR receptors in the ovaries of mice on CR compared with mice fed ad libitum.

\section{Materials and methods \\ Animals}

This study was undertaken in the Department of Physiology Pomeranian Medical University in Szczecin in accordance with the guidelines of the Local Ethical Committee (Use of Laboratory Animals) in Szczecin, Poland.

The experiment was performed on one-month-old C57B1/6 female mice. Twelve mice were divided into two groups: control $(n=6)$ and experimental $(n=6)$. The animals of the control group were given free access to a nutritionally balanced diet in doses of $7 \mathrm{~g} /$ day/per mouse (Murigan, Motycz, Poland) ad libitum. The animals of the experimental group on caloric restriction (CR) were fed ad libitum every other day at the same dose $(7 \mathrm{~g} /$ day/mouse). All animals received water $a d$ libitum. During the experiment, mice were weighted once a week.

The animals were housed in separated cages under controlled conditions of optimum temperature $\left(21{ }^{\circ} \mathrm{C}\right)$ and light (12-hr light/12-hr dark cycle) until the age of 10 months, when animals were weighted and sacrificed with thiopental at a dose of $90 \mathrm{mg} / \mathrm{kg}$ body mass and the ovaries collected.

\section{Morphological analysis of ovarian tissue}

At the end point of the experiment, the ovaries were isolated for histological analysis. They were then fixed in $4 \%$ buffered formalin, embedded in paraffin, and sectioned at a thickness of $3 \mu \mathrm{m}$ with a Microtome HM 325 . The sections were mounted on glass slides, counterstained with hematoxylin and eosin (H\&E), and examined by light microscopy (BX41 microscope, Olympus). 


\section{Immunohistochemistry}

Immunohistochemical reaction of the ERs and the AR

Expression of the ERs and AR were determined immunohistochemically in paraffin-embedded specimens fixed in $4 \%$ buffered formalin. The reactions were performed on deparaffinized and rehydrated sections, which were cut and mounted on microscope slides. The slides were heated in buffer pH9 (DakoTarget Retrieval, Denmark) for $30 \mathrm{~min}$, and endogenous peroxidase was inhibited by Dako REAL peroxidase-blocking solution. Next, antiestrogen receptor and anti-androgen receptor antibodies were applied (both purchased in Thermo Scientific, USA) for $30 \mathrm{~min}$. To visualize the immunohistochemical reaction, Dako REAL EnVision Detection System Peroxidase/DAB/Rabbit/Mouse was used, and the sections were counterstained with Meyer's hematoxylin. Finally, the sections were examined with an Olympus IX81 inverted light microscope (Olympus, Germany) with color camera and CellSens image-processing software (Olympus, Germany).

From each female (AL $n=6$ and $C R n=6$ ), 2 representative sections from each ovary (24 ovaries) were used for examination of ER and AR expressions.

\section{Quantitative image computer analysis of immunohistochemistry}

All preparations were subjected to scanning procedure employing a ScanScope AT2 scanner (Leica Biotechnologies), at $\times 200$ magnification (resolution $0.25 \mu \mathrm{m}$ ). The obtained digital images were analyzed on a computer screen using an ImageScope viewer (version 11.2.0.780, Aperio Technologies, Inc). The percentage of the AR-positive and ER-positive cells was calculated quantitatively for all studied types of ovarian cells using grades:,,-+++ and +++ . In order to obtain reliable and repetitive values, the total number of AR-positive and ER-positive cells was counted in 10 random fields in twelve slides for each group (control and experimental animal ovaries).

\section{Statistical analysis}

Statistical analysis was conducted using the program Statistica 8.0 for Windows (StatSoft, Poland). The arithmetic mean and standard deviation were calculated for quantitative variables in each group. In order to assess normality distribution Shapiro-Wilk test was used. U Mann-Whitney test was performed to assess the significance of differences between the values obtained for each of the groups.

\section{Results}

Weight of animals and histology of ovaries

During the 9 months of experiments, animals from both groups gained weight. The final body mass of females in the CR group did not differ from the body mass of females in the group fed ad libitum (Table 1).

\section{Immunoexpression of the estrogen receptors (ERs) in ovary}

In the ovaries of mice in the experimental group under $\mathrm{CR}$, we found immunoexpression of ERs in granulosa cells, ovarian surface epithelium cells, endothelial cells, and interstitial cells and, in addition, very weak immunoexpression of these receptors also in theca cells and weak immunoexpression in luteal cells (Table 2, Fig. 1).

In the ovaries of animals in the control group, ERs were expressed only in granulosa cells, in ovarian surface epithelium cells, endothelial cells and interstitial cells and was weaker than in mice under CR (Table 2, Fig. 1).

\section{Immunoexpression of the androgen receptor (AR) in ovary}

In the ovaries of mice in the experimental group under $\mathrm{CR}$, we found expression of the AR in granulosa cells, ovarian surface epithelium cells, endothelial cells, and interstitial cells, and also in theca but not in luteal cells (Table 2, Fig. 2). By contrast, in the ovaries of control mice, we found expression of the AR in granulosa cells, luteal cells, ovarian surface epithelium cells, endothelial cells, and interstitial cells (Table 2, Fig. 2). Of note, we didn't find expression of these receptors in theca cells in ovaries of the control group (Table 2, Fig. 2). Furthermore, in ovaries of experimental and control groups we observed a similar high level of expression of the AR in granulosa cells and in surface epithelium cells. In the ovaries of the experimental group on CR, we noted higher expression of the AR in endothelial cells than in ovaries of the control group. In the experimental group, we observed very weak expression of the AR in theca, weak expression in interstitial cells and a lack of immunoreactivity in luteal cells (Table 2, Fig. 2).

In ovaries of the control group, the immunoreactivity of the AR in interstitial cells was similar to the expression of AR in interstitial cells in ovaries of the experimental group. Furthermore, expression of the AR was lower in control mouse ovarian endothelial cells than in experimental mice. We also noted a weak immunoreaction of the AR in luteal cells in ovaries of control group females (Table 2, Fig. 2).

The immunohistochemical evaluation in all sections in all types of ovarian cells was confirmed by quantitative

Table 1 The body mass of female mice of the CR group and the group fed ad libitum (AL)

\begin{tabular}{lccc}
\hline Experimental group & Beginning $[\mathrm{g}] \pm \mathrm{SD}$ & End $[\mathrm{g}] \pm \mathrm{SD}$ & Mass gain [\%] \\
\hline CR female mice & $22.14 \pm 1.97$ & $29.133 \pm 2.46$ & 31.58 \\
AL Female mice & $21.24 \pm 1.15$ & $30.133 \pm 3.35$ & 41.87 \\
\hline
\end{tabular}


Table 2 Immunoexpression of estrogen (ER) and androgen (AR) receptors in the ovaries of mice on CR and fed ad libitum

\begin{tabular}{|c|c|c|c|c|c|c|}
\hline Receptors & Ovarian Surface Epithelium & Granulosa cells & Theca cells & Luteal cells & Endothelial cells & Interstitial cells \\
\hline \multicolumn{7}{|l|}{ Estrogen receptors } \\
\hline Experimental group & +++ & +++ & $+/-$ & + & ++ & ++ \\
\hline Control group & + & ++ & - & - & + & + \\
\hline \multicolumn{7}{|l|}{ Androgen receptor } \\
\hline Experimental group & ++ & +++ & $+/-$ & - & ++ & + \\
\hline Control group & ++ & +++ & - & + & + & + \\
\hline
\end{tabular}

Legend: very strong reaction(+++), strong reaction(++), weak reaction(+), very weak (+/-), no reaction(-)

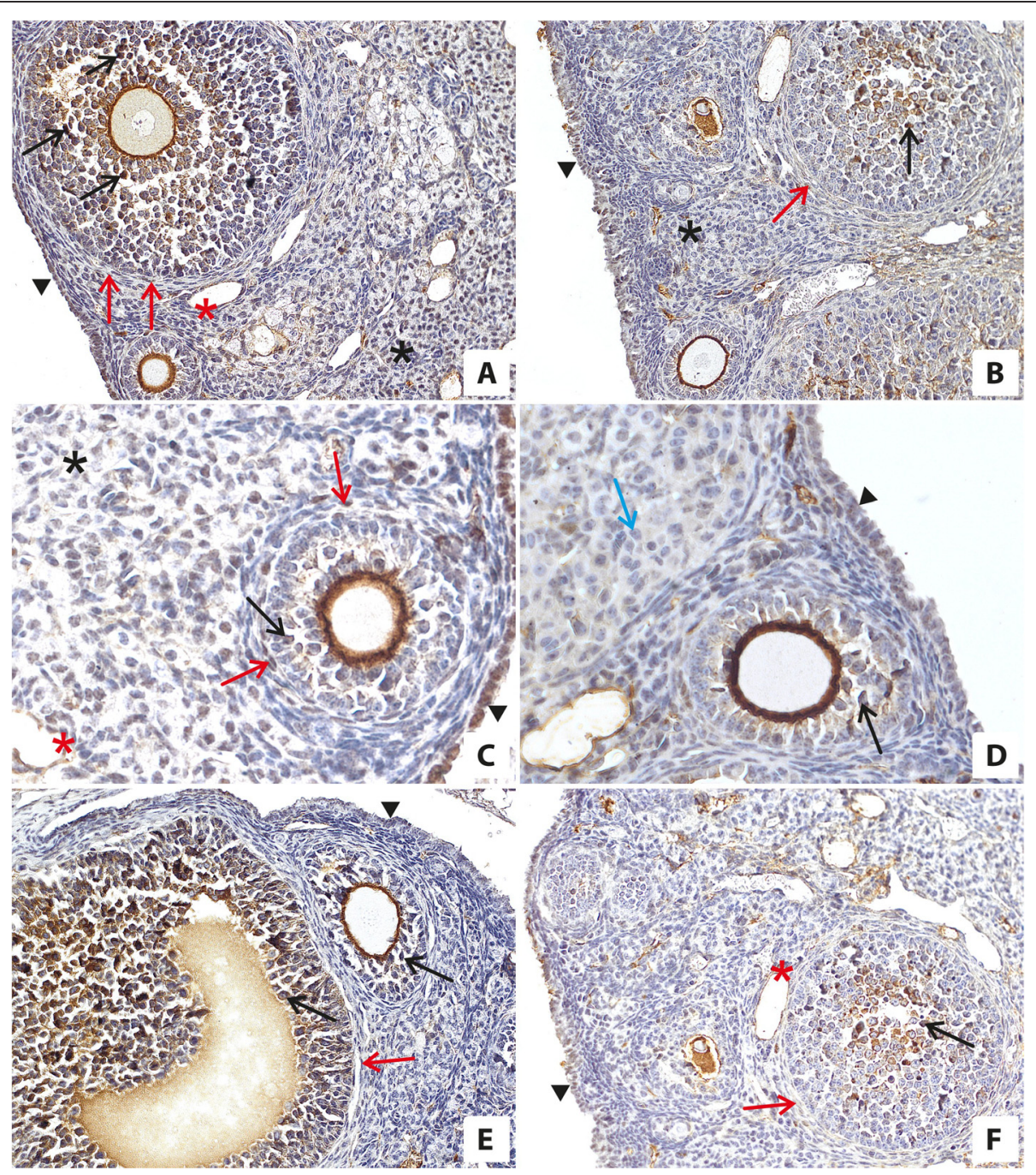

Fig. 1 Immunolocalization and immunoexpression of ERs in the ovaries of mice on CR (a, c, e) and in the ovaries of mice fed ad libitum (b, d, $\mathbf{f})$. The high expression of ERs was observed in ovaries of mice on CR in granulosa cells (black arrow), theca cells (red arrow), ovarian surface epithelium cells (black arrowhead), interstitial cells (black asterisk), and endothelial cells (red asterisk) (a, c, e) compared with expression of ERs in the ovaries of control mice fed ad libitum in granulosa cells (black arrow), ovarian surface epithelium cells (black arrowhead), interstitial cells (black asterisk), and endothelial cells (red asterisk) (b, d, f). There was no immunoreaction in theca cells (b, $\mathbf{f}$; red arrow) and in luteal cells (d; blue arrow) in the ovaries of mice fed ad libitum (b, d, f). Objective magnification: $\mathbf{a}, \mathbf{b}, \mathbf{e}, \mathbf{f}, \times 20 ; \mathbf{c}, \mathbf{d}, \times 40$ 


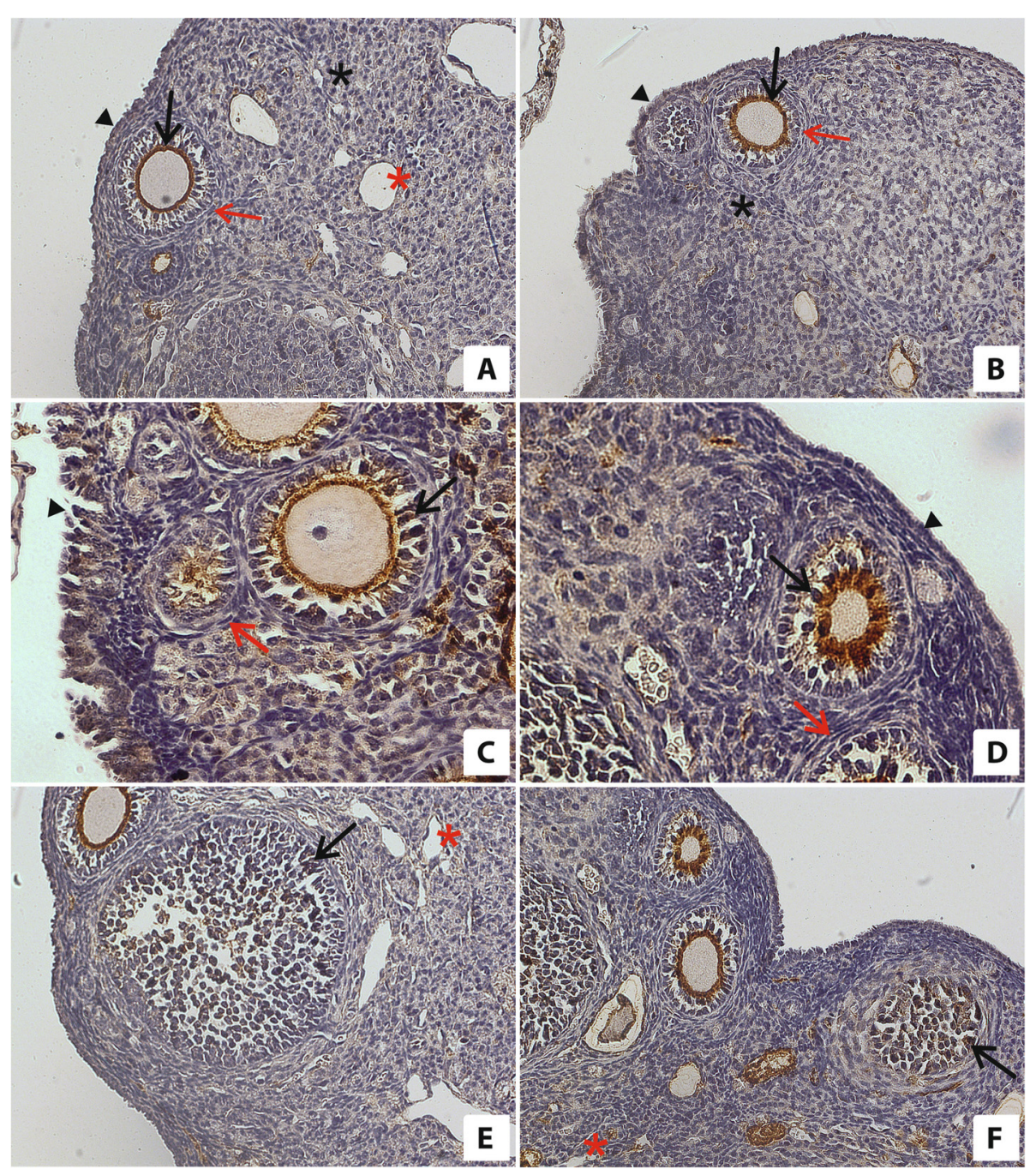

Fig. 2 Immunolocalization and immunoexpression of the AR in the ovaries of mice on CR (a, $\mathbf{c}, \mathbf{e})$ and in the ovaries of mice fed ad libitum (b, $\mathbf{d}, \mathbf{f}$ ). One can see a similar expression of the AR in granulosa cells (black arrow) and ovarian surface epithelium cells (black arrowhead) in ovaries of mice on $C R(\mathbf{a}, \mathbf{c}, \mathbf{e})$ and in ovaries of mice fed ad libitum $(\mathbf{b}, \mathbf{d}, \mathbf{f})$. Expression of the AR in interstitial cells is shown by black asterisks in ovaries of mice fed ad libitum (b) and in the ovaries of mice on CR (a). Red asterisks indicate expression of AR in endothelial cells in the ovaries of mice fed ad libitum (f) and in the ovaries of mice on CR (a, e). There was no immunoreactions to the AR in theca cells (red arrow) in the ovaries of mice fed ad libitum ( $\mathbf{b}$, $\mathbf{d})$. There was very weak expression of the AR in theca cells (red arrow) in the ovaries of mice on CR (a, c). Objective magnification: $\mathbf{a}, \mathbf{b}, \mathbf{e}, \mathbf{f}, \times 20 ; \mathbf{c}, \mathbf{d}, \times 40$

image analysis and expressed as percentage of positive cells. Results of quantitative analysis are presented in Table 3. Results indicated with asterix (*) are statistically significant $(\mathrm{p}<0,05)$.

\section{Discussion}

It is known that caloric restriction prolongs life span in many species $[21,24,26]$. In our recent work, we reported that ovaries of mice fed ad libitum had smaller numbers of primordial, primary, and preantral follicles than ovaries of mice on CR [25]. Here, we wanted to check whether CR influences the expression of ERs or the AR in murine ovaries. This is an important question, because estrogens and androgens have a crucial role in the normal function of the reproductive system $[1,4-6$, $12,14,15]$. The salient observation of our study is an increase in expression of ERs in the ovaries of animals on $\mathrm{CR}$. By contrast, in female mice of reproductive age, expression of the AR in ovarian cells did not change, regardless of whether mice were under $\mathrm{CR}$ or fed $a d$ libitum. Specifically, we found similar expression of the AR in both groups of animals, particularly in granulosa cells and in ovarian surface epithelium cells. We also observed individual theca, interstitial, and endothelial AR-positive cells.

An increase in the level of androgens in females is associated with obesity, and androgens reduce hypothalamic sensitivity to steroid negative feedback [31]. In our 
Table 3 The percentage of AR and ER positive cells in ovaries in CR and fed ad libitum mice. Data expressed as mean \pm SD

\begin{tabular}{|c|c|c|c|c|c|}
\hline \multirow[t]{2}{*}{ Group } & & \multicolumn{2}{|l|}{ Control } & \multicolumn{2}{|l|}{ Experimental } \\
\hline & & $A R$ & $E R$ & $A R$ & $E R$ \\
\hline \multirow[t]{4}{*}{ Ovarian surface epithelium } & Lack of reaction (-) & $9,2 \pm 13,0$ & $22,5 \pm 4,2$ & $10,3 \pm 12,2$ & $6,5^{*} \pm 8,5$ \\
\hline & Weak reaction $(+)$ & $28,3 \pm 11,7$ & $52,9 \pm 6,8$ & $15,7^{*} \pm 13,4$ & $15,1^{*} \pm 6,3$ \\
\hline & Strong reaction $(++)$ & $62,0 \pm 15,6$ & $22,1 \pm 7,1$ & $56,3 \pm 15,3$ & $6,9^{*} \pm 3,5$ \\
\hline & Very strong reaction $(+++)$ & $0,6 \pm 1,8$ & $2,5 \pm 2,2$ & $17,7^{*} \pm 6,6$ & $71,5^{*} \pm 12,6$ \\
\hline \multirow[t]{4}{*}{ Granulosa cells } & Lack of reaction $(-)$ & $10,0 \pm 11,9$ & $0,2 \pm 0,7$ & $13,6 \pm 7,5$ & $0,1 \pm 0,4$ \\
\hline & Weak reaction (+) & $6,4 \pm 3,1$ & $9,5 \pm 9,0$ & $14,2^{*} \pm 5,9$ & $2,3^{*} \pm 3,0$ \\
\hline & Strong reaction $(++)$ & $26,5 \pm 8,9$ & $72,7 \pm 10,4$ & $25,9 \pm 7,7$ & $18,7^{*} \pm 6,0$ \\
\hline & Very strong reaction $(+++)$ & $57,1 \pm 10,9$ & $17,6 \pm 9,5$ & $46,3^{*} \pm 6,2$ & $79,0^{*} \pm 6,5$ \\
\hline \multirow[t]{4}{*}{ Theca cells } & Lack of reaction $(-)$ & $89,4 \pm 6,4$ & $79,1 \pm 6,8$ & $34,8^{*} \pm 6,1$ & $28,7^{*} \pm 10,7$ \\
\hline & Weak reaction $(+)$ & $9,0 \pm 4,9$ & $11,3 \pm 4,2$ & $49,7^{*} \pm 6,5$ & $50,2^{*} \pm 9,9$ \\
\hline & Strong reaction $(++)$ & $0,5 \pm 1,4$ & $7,9 \pm 4,6$ & $11,1^{*} \pm 4,3$ & $13,3 \pm 6,0$ \\
\hline & Very strong reaction $(+++)$ & $1,0 \pm 3,2$ & $1,6 \pm 2,6$ & $4,2^{*} \pm 4,9$ & $7,7^{*} \pm 4,5$ \\
\hline \multirow[t]{4}{*}{ Luteal cells } & Lack of reaction $(-)$ & $24,9 \pm 7,8$ & $76,8 \pm 15,2$ & $93,1^{*} \pm 1,9$ & $33,8^{*} \pm 7,8$ \\
\hline & Weak reaction (+) & $73,7 \pm 6,9$ & $14,3 \pm 7,3$ & $6,9^{*} \pm 2,0$ & $50,6^{*} \pm 5,5$ \\
\hline & Strong reaction $(++)$ & $1,3 \pm 0,8$ & $8,3 \pm 8,1$ & $0,1^{*} \pm 0,2$ & $14,1 \pm 5,0$ \\
\hline & Very strong reaction $(+++)$ & $0,1 \pm 0,2$ & $0,6 \pm 0,8$ & $0,1 \pm 0,2$ & $1,5 \pm 1,6$ \\
\hline \multirow[t]{4}{*}{ Endothelial cells } & Lack of reaction $(-)$ & $20,6 \pm 9,6$ & $20,8 \pm 9,7$ & $0,1^{*} \pm 0,2$ & $17,7 \pm 7,8$ \\
\hline & Weak reaction (+) & $70,4 \pm 10,6$ & $50,9 \pm 7,7$ & $21,0^{*} \pm 12,6$ & $15,5^{*} \pm 8,4$ \\
\hline & Strong reaction $(++)$ & $8,1 \pm 4,8$ & $25,9 \pm 11,7$ & $52,6^{*} \pm 5,2$ & $47,1^{*} \pm 7,7$ \\
\hline & Very strong reaction $(+++)$ & $0,8 \pm 1,8$ & $2,4 \pm 3,2$ & $26,3^{*} \pm 9,2$ & $19,7^{*} \pm 12,9$ \\
\hline \multirow[t]{4}{*}{ Interstitial cells } & Lack of reaction $(-)$ & $5,5 \pm 8,3$ & $24,0 \pm 5,0$ & $19,1^{*} \pm 11,3$ & $6,3^{*} \pm 4,4$ \\
\hline & Weak reaction (+) & $72,4 \pm 7,6$ & $47,6 \pm 5,8$ & $79,4 \pm 10,7$ & $21,7^{*} \pm 10,3$ \\
\hline & Strong reaction $(++)$ & $20,2 \pm 11,6$ & $22,8 \pm 5,9$ & $1,4^{*} \pm 1,5$ & $56,8^{*} \pm 6,3$ \\
\hline & Very strong reaction $(+++)$ & $1,8 \pm 2,2$ & $5,7 \pm 3,9$ & $0,1 \pm 0,3$ & $15,3^{*} \pm 9,7$ \\
\hline
\end{tabular}

${ }^{*} p<0,05$ vs control

experiment, we did not observe differences in weight between mice in experimental and control groups. HułasStasiak et al. [19] found that expression of the AR decreases during follicular development. In our previous work we observed higher numbers of primordial, primary, and preantral follicles in ovaries of mice on CR than in the control group [25]. Since the development of follicles in these early stages depends on androgen levels $[8,12,15,16]$, one can speculate that follicular development is normal in the androgen-dependent stages of folliculogenesis in mice under CR and diminished in the estrogen-dependent stages due to decreased levels of estrogens. Because the early stages of follicular development were not influenced by $\mathrm{CR}$, we assume that androgen levels during the $\mathrm{CR}$ experiment were not changed and that this was the reason for the lack of change in expression of the AR.

Moreover, a decrease in testosterone level due to dietary restriction together with premenopausal weight loss has been observed in women [32]. The lack of change in weight in our mice is probably related to a lack of change in expression of the AR, most likely because of a lack of change in androgen level. Other groups [33] found that expression of the AR did not change in ovaries of postmenopausal women, in spite of a permanent decrease in androgen plasma level. Interestingly, in other reproductive organs, it was shown that changes in expression of the AR do not depend on androgen levels in plasma [34].

In contrast to the lack of AR expression changes, we observed differences in expression of ERs in murine ovaries between experimental and control groups. Specially, we noted higher expression of ERs in granulosa cells and surface epithelium cells in ovaries of mice on $\mathrm{CR}$ compared with ovaries of mice fed ad libitum. In parallel, we also observed a slightly increased expression of ERs in theca, luteal, endothelial, and interstitial cells.

Nilsson et al. [35] reported that expression of ER $\alpha$ is reduced in adipocytes from obese female mice compared with normal-weight mice. Moreover, Foryst-Ludwig et al. [36] observed that ER $\beta$ knockout mice fed a highfat diet had enhanced PPAR $\gamma$ signaling, increased fat 
mass, and improved insulin sensitivity. This study provided evidence for a role of estrogens in overweight conditions and obesity [36]. In our experiment, the expression of ERs in the ovaries of mice on CR increased, and we observed no reduction in body mass. This result is in accordance with results obtained in previous studies of humans and rodents concerning the influence of estrogens level on weight and the amount of adipose tissue $[35,36]$. It has been demonstrated that, while estrogen treatment reduces adipose tissue mass in postmenopausal women, the decrease in estrogen levels after ovariectomy leads to an increase in adipose tissue mass [37]. To explain this finding, Mauvais-Jarvis [23] reported that ERs control energy intake and expenditure.

The ovarian expression of ERs is regulated by estrogen levels in blood plasma, and in ER knockout mice, estrogen and LH plasma levels are elevated [38]. This suggests the presence of an equilibrium between estrogen and LH levels and expression of ERs at the protein level [38]. In our study, we noted an increase in ER expression in the ovaries of CR female mice compared with littermates fed ad libitum. This result could potentially be explained by a decrease in estrogen level in blood plasma in animals on CR. A decrease in estrogen and LH levels in rodents and heifers on a CR diet was observed by $\mathrm{Li}$ and Hussein [39, 40]. Similar results were obtained by Williams et al. [41] in a study of premenopausal women on $\mathrm{CR}$ and exposed to exercise.

In our experiment, we did not observe a decrease in the body mass of female mice after 9 months of CR. It is known that after menopause or ovariectomy in humans the decrease in estrogens is paralleled by an increase in body weight [23]. We assume that the lack of a decrease in body weight in our mice under $\mathrm{CR}$ is due to a decrease in estrogen levels, which leads to a decrease in energy expenditure in female mice. This conclusion, however, requires further study, including direct measurement of estrogen levels in blood plasma. We also noted increased liver weight and steatosis in female mice on CR compared with control mice, which can be linked to a decrease in energy expenditure and suggests energy savings (unpublished data). In support of this possibility, Rogers et al. [42] observed hepatic steatosis and a decrease in energy expenditure in ovacteromized mice in which the estrogen level decreased. Decreased production of estrogens may be linked to decreased activity of aromatase P450, which is regulated by IGF-1 level [43]. In fact, the decreased level of IGF-1 in plasma during $\mathrm{CR}$ in female rats was confirmed by $\mathrm{Li}$ et al. [44]. It is also possible that fat depots in CR females are bigger than in control animals that were fed ad libidum. Even if we did not notice increase in body weight in animals under $\mathrm{CR}$ the potential re-distribution of fat tissue requires further studies.
In conclusion, prolonged CR (9 months) in female mice leads to increased expression of ERs, while at the same time it does not affect expression of the AR in ovarian cells. Caloric restriction results in lower level of estrogen in circulating blood which leads to higher sensitivity of cells to this hormone. We envision that return to normal diet after period of CR increases number and enhances maturation and function of follicles due to improved responsiveness of ovarian tissue to estrogens action and may be helpful in reproductive success.

\section{Abbreviations}

CR: caloric restriction; AR: androgen receptor; ERs: estrogen receptors; FSH: follicle stimulating hormone; LH: luteinizing hormone; IGF-1: insulin-like growth factor 1; WT: wild type.

\section{Competing interests}

The authors declare that they have no competing interests.

\section{Authors' contributions}

SSG: planned the studies on mice ovaries, collected ovaries from the mice, performed morphological and immunohistochemical evaluation of ovarian sections, analyzed the results, defined conclusions and wrote the manuscript, ML: supervised the work, participated in morphological and

immunohistochemical analysis of ovarian sections, helped in writing the manuscript, KP: participated in performing the experiment with caloric restriction, collected ovaries from the mice, participated in morphological and immunohistochemical analysis of ovarian sections, helped in writing the manuscript, MG: performed quantitative image computer analysis of immunohistochemistry and performed statistical analysis, KG: performed the experiment with caloric restriction, collected material, MZR: designed the study and supervised the work, helped in writing the manuscript and corrected the final version of the manuscript. All authors read and approved the final manuscript.

\section{Author details}

'Department of Physiology Pomeranian Medical University, Powstańców Wielkopolskich 72, 70-111 Szczecin, Poland. '2Department of Histology and Developmental Biology, Pomeranian Medical University, Żołnierska 48, 71-210 Szczecin, Poland. ${ }^{3}$ Stem Cell Biology Program, James Graham Brown Cancer Center, University of Louisville, Louisville, Ky, USA.

Received: 28 January 2015 Accepted: 4 August 2015

Published online: 13 August 2015

\section{References}

1. Li X, Zhang H, Sheng X, Li B, Zhou J, Xu M, et al. Immunoreactivities of androgen receptor, estrogen receptors, p450arom, p450c17 proteins in wild ground squirrels ovaries during the nonbreeding and breeding seasons. J Ovarian Res. 2012;5:26

2. Simpson ER. Sources of estrogen and their importance. J Steroid Biochem Mol Biol. 2003;86:225-30

3. Nelson LR, Bulun SE. Estrogen production and action. J Am Acad Dermatol. 2001:45:S116-24.

4. Hamilton KJ, Arao Y, Korach KS. Estrogen hormone physiology: reproductive findings from estrogen receptor mutant mice. Reprod Biol. 2014;14:3-8.

5. Hewitt CS, Couse JF, Korach KS. Estrogen receptor transcription and transactivation: Estrogen receptor knockout mice - what their phenotypes reveal about mechanisms of estrogen action. Breast Cancer Res. 2000;2:345-52.

6. Sar M, Welsch F. Differential expression of estrogen receptor - $b$ and estrogen receptor - a in rat ovary. Endocrinology. 1999;140:963-71.

7. Juengel JL, Heath DA, Quirke LD, McNatty KP. Oestrogen receptor alpha and beta, androgen receptor and progesterone receptor mRNA and protein localization within the developing ovary and in small growing follicles of sheep. Reproduction. 2006;131:81-92.

8. Gervasio CG, Bernuci MP, Silve-de-Sa MF, Japur de Sa Rosa-e-Silva AC. The role of androgen hormones in early follicular development. ISRN Obstet Gynecol. 2014;2014:818010. 
9. Miller WL, Auchus RJ. The molecular biology, biochemistry, and physiology of human steroidogenesis and its disorders. Endocr Rev. 2011;32:81-151.

10. Palermo R. Differential action of FSH and LH during folliculogenesis. Reprod Biomed Online. 2007;15:326-37.

11. Hillier SG, Whitelaw PF, Smyth CD. Follicular oestrogen synthesis: the two cell, two-gonadotrophin model revisited. Mol Cel Endocrinol. 1994;100:51-4.

12. Walters KA, Allan CM, Handelsman DJ. Androgen action and the ovary. Biol Reprod. 2008;78:380-9.

13. Gleicher N, Weghofer A, Barad DH. The role of androgens in follicle maturation and ovulation induction: friend or foe of infertility treatment. Reprod Biol Endocrinol. 2011;9:116.

14. Hampton JH, Manikkam M, Lubabn DB, Smith MF, Garverick HA. Androgen receptor mRNA expression in bovine ovary. Domest Anim Endocrinol. 2004;27:81-8.

15. Tetsuka M, Whitelaw PF, Bremner WJ, Milar MR, Smyth CD, Hillier SG Developmental regulation of androgen receptor in rat ovary. J Endocrinol. 1995; 145:535-43.

16. Rice S, Ojha K, Whitehead S, Mason H. Stage-specific expression of androgen receptor, follicle-stimulating hormone receptor, and anti-Müllerian hormone type II receptor in single, isolated, human preantral follicles: relevance to polycystic ovaries. J Clin Endocrinol Metab. 2007;92:1034-40.

17. Sen A, Hammes SR. Granulosa cell-specific androgen receptors are critical regulators of ovarian development and function. Mol Endocrinol. 2010;24:1393-403.

18. Walters KA, Middleton $L$, Joseph SR, Hazra R, Jimenez M, Simanainem U, et al. Targed loss of androgen receptor signaling in murine granulose cells of preantral and antral follicles cause female subfertility. Biol Reprod. 2012;87:1-11.

19. Hułas-Stasiak M, Gawron A. Distribution of androgen and progesterone receptors in the spiny mouse (Acomyscahirinus) ovary during postnatal life. Reprod Biol. 2010;10:37-51.

20. Dupont J, Reverchon M, Bertoldo MJ, Froment P. Nutritional signals and reproduction. Mol Cell Endocrinol. 2014;382:527-37.

21. Masoro EJ, McCarter RJM, Katz MS, McMahan CA. Dietary restriction alters the characteristics of glucose fuel use. J Gerontol BiolSci. 1992;47:B202-8.

22. Selesniemi K, Lee HJ, Tilly JL. Moderate caloric restriction initiated in rodents during adulthood sustains function of the female reproductive axis into advanced chronological age. Aging Cell. 2008;7:622-9.

23. Mauvais-Jarvis F. Estrogen and androgen receptors: regulators of fue homeostasis and emerging targets for diabetes and obesity. Trends Endocrinol Metab. 2011;22:24-33.

24. Masoro EJ. Overview of caloric restriction and ageing. Mech Ageing Dev. 2005;126:913-22.

25. Grymuła K, Piotrowska K, Słuczanowska-Głąbowska S, Mierzejewska K, Tarnowski M, Tkacz M, et al. Positive effects of prolonged caloric restriction on the population of very small embryonic-like stem cells - hematopoietic and ovarian implication. J Ovarian Res. 2014;7:68.

26. Osborne TB, Mendel LB, Ferry EL. The effect of retardation of growth upon the breeding period and duration of life in rats. Science. 1917;45:294-5.

27. Gutierrez CG, Oldham J, Bramley TA, Gong JG, Campbell BK, Webb R. The recruitment of ovarian follicles in enhanced by increased dietary intake in heifers. J Anim Sci. 1997;75:1876-84.

28. Amstrong DG, Gong JG, Gardner JO, Baxter G, Hogg CO, Webb R. Steroidogenesis in bovine granulose cells: the effect of short-term changes in dietary intake. Reproduction. 2002;123:371-8.

29. Nelson JF, Gosden RG, Felicio LS. Effect of dietary restriction on estrous cyclicity and follicular reserves in aging C57BL/6 J mice. Biol Reprod. 1985:32:515-22.

30. Słuczanowska-Głąbowska S, Laszczyńska M, Piotrowska K, Głąbowski W, Rumianowski B, Masternak $M$, et al. The effect of calorie restriction on the presence of apoptotic ovarian cells in normal Wild-type mice and lowplasma-IGF-1 Laron dwarf mice. J Ovarian Res. 2013;6:67.

31. Brill DS, Moenter SM. Androgen receptor antagonism and an insulin sensitizer block the advancement of vaginal opening by high-fat diet in mice. Biol Reprod. 2009;81:1093-8.

32. Svendsen PF, Jensen FK, Holst JJ, Haugaard SB, Nilas L, Madsbad S. The effect of very low calorie diet on insulin sensitivity, beta cell function, insulin clearance, incretin hormone secretion, androgen levels and body composition in obese young women. Scand J Clin Lab Invest. 2012;72:410-9.

33. Brodowska A, Laszczyńska M, Starczewski A, Brodowski J, Masiuk M, Domagała W. Immunohistochemical analysis of steroid receptors in ovaries of postmenopausal women - effects of aging and hormone status. Histol Histopathol. 2010;25:1009-16.

34. Słuczanowska-Głąbowska S, Laszczyńska M, Wylot M, Głąbowski W, Piasecka M, Gączarzewicz D. Morphological and immunohistochemical compare of three rat prostate lobes (lateral, dorsal and ventral) in experimental hyperprolactimemia. Folia Histochem Cytobiol. 2010;48:447-54.

35. Nilsson M, Dahlman I, Ryder M, Nordstrom EA, Gustafsson JA, Arner P, et al. Oestrogen receptor alpha gene expression levels are reduced in obese compared to normal weight females. Int J Obes. 2007;31:900-7.

36. Foryst-Ludwig A, Clemenz M, Hohmann S, Hartge M, Sprang C, Frost N, et al. Metabolic action of estrogen receptor beta (ER beta) are mediated by a negative cross-talk with PPARgamma. PLoS Genetics. 2008;4:e1000108.

37. Kramarova TV, Wright KD, Pongratz I. The role of the estrogen receptors in obesity. Drug Discovery Today: Disease Mechanisms/Endocrine Metabolism. 2009;6:e49-54.

38. Walker VR, Korach KS. Estrogen receptor knockout mice as a model for endocrine research. ILAR J. 2004;45:455-61.

39. Li L, Fu YC, Xu JJ, Lin XH, Chen XC, Zhang XM, et al. Caloric restriction promotes the reserve of follicle pool in adult female rats by inhibiting the activation of mammalian target of rapamycin signaling. Reprod Sci. 2015;22:60-7.

40. Hussein HA, Abdel-Raheem SM. Effect of feed intake restriction on reproductive performance and pregnancy rate in Egyptian buffalo heifers. Trop Anim Health Prod. 2013;45:1001-6.

41. Williams NI, Reed JL, Leidy HJ, Legro RS, De Souza MJ. Estrogen and progesterone exposure in reduced in response to energy deficiency in women aged 25-40 years. Hum Reprod. 2010;25:2328-39.

42. Rogers NH, Perfield JW, Strissel KJ, Obin MS, Greenberg AS. Reduced energy expenditure and increased inflammation are early events in the development of ovariectomy-induced obesity. Endocrinology. 2009;150:2161-8.

43. Zhang B, Shozu M, Okada M, Ishikawa H, Kasai T, Murakami K, et al. Insulinlike growth factor I enhances the expression of aromatase P450 by inhibiting autophagy. Endocrinology. 2010;151:4949-58.

44. Li L, Yu-cai F, Jin-jie X, Xiao-chun C, Xuan-hao L, Li-li L. Caloric restriction promotes the reproductive capacity of female rats via modulating the level of insulin-like growth factor-1 (IGF-1). Gen Comp Endocriol. 2011;174:232-7.

\section{Submit your next manuscript to BioMed Central and take full advantage of:}

- Convenient online submission

- Thorough peer review

- No space constraints or color figure charges

- Immediate publication on acceptance

- Inclusion in PubMed, CAS, Scopus and Google Scholar

- Research which is freely available for redistribution 